Ambiente \& Água - An Interdisciplinary Journal of Applied Science
ISSN 1980-993X - doi:10.4136/1980-993X
www.ambi-agua.net
E-mail: ambi.agua@gmail.com

\title{
Enhancing arsenic removal from groundwater at household level with naturally occurring iron
}

\author{
doi:10.4136/ambi-agua.1815
}

Received: 03 Dec. 2015; Accepted: 17 May 2016

\author{
Anitha Kumari Sharma ${ }^{1}$; Sabrina Sorlini ${ }^{2}$, Barbara Marianna Crotti ${ }^{3}$; \\ Maria Cristina Collivignarelli ${ }^{4}$; Jens Christian Tjell ${ }^{1}$; Alessandro Abbà ${ }^{*}$ \\ ${ }^{\mathbf{1}}$ Technical University of Denmark, Miljoevej, Lyngby, Denmark \\ ${ }^{2}$ University of Brescia, Brescia, Italy \\ Department of Civil, Environmental, Architectural Engineering and Mathematics \\ ${ }^{3}$ ASMia Srl, Mortara, Pavia, Italy \\ ${ }^{4}$ University of Pavia, Pavia, Italy \\ Department of Civil and Architectural Engineering \\ *Corresponding author: e-mail: abba78@unipv.it, \\ anitha.sharma@innofond.dk, sabrina.sorlini@unibs.it, b.crotti@asmia.eu, \\ mcristina.collivignarelli@unipv.it, jct@env.dtu.dk
}

\begin{abstract}
A supply of drinking water low in Arsenic (As) prevents arsenic poisoning. The presence of high concentrations of iron $(\mathrm{Fe})$ in groundwater under the alluvial plains of the large rivers in Southeast Asia is a prerequisite for the simple removal of As. This study investigated the mechanisms and possibilities for enhancing As removal with naturally occurring $\mathrm{Fe}$ in a reliable, low cost and sustainable way. The results of the study show that As removal with $\mathrm{Fe}$ is greatly enhanced by the addition of an oxidizing agent (preferably $\mathrm{KMnO}_{4}$ ) immediately after the pumping of groundwater. Further enhancement of As removal in the presence of $\mathrm{Fe}$ can be achieved by adding a small volume of a concentrated basic solution of $\mathrm{MnO}_{4}{ }^{-}$and $\mathrm{AlO}_{2}^{-}$, which has a combined oxidation, coagulation and buffering capacity. Best results were obtained when this solution was mixed with the groundwater immediately after its pumping until a pale pink color appeared. Maximum required reaction time was 10 minutes and subsequent filtration of the water was able to reduce the As concentration to near zero. Concentrations of $\mathrm{MnO}_{4}^{-}$and $\mathrm{AlO}_{2}^{-}$can be varied in the solution to achieve sufficient As removal to suit different $\mathrm{Fe} / \mathrm{As}$ ratios and the presence of interfering co-occurring anions.
\end{abstract}

Keywords: aluminum, metal removal, oxidation.

\section{Melhoria na remoção de arsênio de água subterrânea em nível doméstico com ferro de ocorrência natural}

\section{RESUMO}

O abastecimento de água potável com baixa concentração de arsênio (As) é uma das soluções contra a Arsenicose. A presença de altas concentrações de ferro (Fe) na água subterrânea das várzeas dos grandes rios no sudeste da Ásia é um pré-requisito para uma remoção simplificada de arsênio. O objetivo deste estudo foi avaliar os mecanismos e as 
possibilidades de melhorar a remoção de arsênico de águas subterrâneas com a ocorrência natural de ferro de modo confiável, de baixo custo e sustentável. Os resultados mostraramm que a remoção do arsênio com ferro é mais efetiva com a adição de um agente oxidante (de preferência com $\mathrm{KMnO}_{4}$ ) imediatamente após o bombeamento de águas subterrâneas. Uma melhoria adicional na remoção do arsênio na presença de ferro pode ser alcançada pela adição de um pequeno volume de uma solução concentrada de $\mathrm{MnO}_{4}{ }^{-}$básico e $\mathrm{AlO}_{2}{ }^{-}$, que tem um efeito combinado de oxidação, coagulação e capacidade tampão. Os melhores resultados foram obtidos quando a solução era misturada imediatamente depois de bombear água até que se adquira uma cor rosa-pálido. O tempo máximo de reação necessário foi de dez minutos e uma subsequente filtração da água pode reduzir a concentração de arsênio até próximo de zero. As concentrações de $\mathrm{MnO}_{4}{ }^{-}$e $\mathrm{AlO}_{2}{ }^{-}$podem ser variadas na solução de modo a obter uma remoção de arsênio suficiente para satisfazer diferentes taxas de Fe/AS e a presença de ânions de interferência simultânea.

Palavras-chave: alumínio, oxidação, remoção de metais.

\section{INTRODUCTION}

Occurrence of inorganic Arsenic (As) in groundwaters under the alluvial plains of the large rivers in Southeast Asia (West Bengal, Bangladesh, Vietnam and other regions) may seriously and adversely affect the health of the population, resulting in skin diseases and various kinds of cancer (WHO, 2011). The prevailing national Maximum Concentration Level (MCL) value for drinking water in most of the countries in Southeast Asia is $50 \mu \mathrm{g} \mathrm{L}^{-1}$, and it is estimated that more than 40 million people are exposed to As concentrations above that threshold (Smedley and Kinniburgh, 2002; Chakraborti et al., 2004; Berg et al., 2007).

Various measures like the installation of As-free deep-tube wells, the reintroduction of surface water, rainwater harvesting, supplying of bottled water, piped water supply and As removal using various treatment methods have been suggested as mitigating options (Ahmed and Rahman, 2003). One unique solution may not be appropriate for the vast As-contaminated regions, as the best choice depends on many factors, such as affordability (economy, time), availability of alternative water sources, flexibility in adopting a new technology, awareness, etc. Low-cost treatment of groundwater for As removal at the household level can a viable option for safeguarding water supplies, especially when individuals are willing to adopt simple procedures to obtain good drinking water.

The chemistry involved in the efficient yet simple removal of As(III) with iron (Fe) is the oxidation of $\mathrm{As}(\mathrm{III})$ to $\mathrm{As}(\mathrm{V})$ and concurrent adsorption of $\mathrm{As}(\mathrm{V})$ and $\mathrm{As}(\mathrm{III})$ onto precipitating iron-hydroxides $\left(\mathrm{Fe}(\mathrm{OH})_{3}\right)$. Oxidation of $\mathrm{As}(\mathrm{III})$ to $\mathrm{As}(\mathrm{V})$ takes place only in parallel to the oxidation of $\mathrm{Fe}$ added as $\mathrm{Fe}(\mathrm{II})$, and most probably due to intermediate oxidants formed during oxidation of $\mathrm{Fe}$ (II) to $\mathrm{Fe}$ (III) in presence of air (Hug and Leupin, 2003).

Subsequent removal of the formed $\mathrm{Fe}(\mathrm{OH})_{3}$ flocs by filtration significantly improves As removal.

Simple household treatment methods based on oxidation, coagulation (with $\mathrm{Al}$ or $\mathrm{Fe}$ salts) and filtration are available and implemented in the field for removal of Arsenic (BAMWSP, 2001, Cheng et al., 2004). Oxidation with air/oxygen is a very slow process, as it requires days rather than hours to be completed (Cherry et al., 1979); therefore, a more effective oxidation of $\mathrm{As}(\mathrm{III})$ can be obtained by means of chemical $\left(\mathrm{KMnO}_{4}, \mathrm{Ca}(\mathrm{ClO})_{2}\right.$ or $\mathrm{NaClO}$ ), photochemical (UV+Citrate), and photocatalytic processes. Sharma (2006), Sorlini and Gialdini (2010) showed that a complete oxidation of As(III) into As(V) can be obtained with $\mathrm{KMnO}_{4}$ during the first minute of oxidation in pure water spiked with As(III), while an oxidation of $80 \%$ after the first minute and $100 \%$ after 15 minutes was obtained for raw groundwater. However, most of the results from the Bengal Delta show that these methods are 
often not able to decrease the concentration of As to below the Indian and Bangladeshi MCL of $50 \mu \mathrm{g} \mathrm{L}^{-1}$ (BAMWSP, 2001), and this is mostly due to insufficient oxidant and/or coagulant amounts. Furthermore, people are reluctant to use some of the methods due to the bad taste and odor from oxidants like $\left(\mathrm{Ca}(\mathrm{ClO})_{2}\right.$ or $\left.\mathrm{NaClO}\right)$ (BAMWSP, 2001).

The groundwater below the Southeast Asian alluvial plains is mostly in the near-neutral $\mathrm{pH}$ range with trivalent arsenite (As(III)) being the predominant As species; moreover, several studies have shown that groundwater with high As concentrations also contain higher iron $(\mathrm{Fe})$ concentrations. For example, in Bangladesh, $74 \%$ of the tube wells with As concentrations higher than $50 \mu \mathrm{g} \mathrm{L}^{-1}$ also have $\mathrm{Fe}^{2+}$ concentrations higher than $2 \mathrm{mg} \mathrm{L}^{-1}$ (BGS, 2003), which is above the MCL for Fe in drinking water (WHO, 2011). The occurrence of As in the Bengal Delta is of natural origin and microbially mediated reductive dissolution of $\mathrm{Fe}$ hydroxides with adsorbed $\mathrm{As}$ and $\mathrm{P}$ is the most accepted theory for the elevated As concentrations up to $4000 \mu \mathrm{g} \mathrm{L}^{-1}$ (Smedley and Kinniburgh, 2002). Hence, taking advantage of the naturally occurring $\mathrm{Fe}$ for As removal would be an ideal solution, as indicated by various authors (Hug et al., 2008; Mamtaz and Bache, 2001; Roberts et al., 2004; Meng et al., 2001).

For these reasons, oxidization with potassium permanganate is an interesting option for arsenic removal due to the fast oxidation kinetics. Potassium permanganate is also readily available in developing countries, and it is more stable than bleaching powder and has a long shelf life. Simple options for the application of this process based on As oxidation with potassium permanganate and chemical precipitation by means of the natural occurring Iron have been evaluated by different authors (Ahmed, 2013). Bortoloi et al. (2013) highlighted that the high efficiency, an extremely low cost, safety, non-requirement of power and simplicity of operation make the technique potentially viable for rural application. Removal of As with Fe depends on many factors and around neutral $\mathrm{pH}$ the most important one is the oxidation state of As. According to Roberts et al. (2004) approximately 18 times more Fe is required for $\mathrm{As}(\mathrm{III})$ compared with arsenate $(\mathrm{As}(\mathrm{V}))$ to achieve similar As removals. In addition, co-occurrence of high levels of anions like phosphate $(\mathrm{P})$, and silicate $(\mathrm{Si})$ decreases removal of As(V) (Smedley and Kinniburgh, 2002; Hug et al., 2008; Mamtaz and Bache, 2001; Roberts et al., 2004; Meng et al., 2001). Previous field investigations (Sharma et al., 2005 ) with varying $\mathrm{P}$ and $\mathrm{Si}$ concentrations and naturally occurring Fe showed that an $\mathrm{Fe} / \mathrm{As}(\mathrm{III})>120(\mathrm{M} / \mathrm{M})$ is required to achieve residual As concentrations below the MCL of $50 \mu \mathrm{g} \mathrm{L}^{-1}$ which will limit the method to only $14 \%$ of the tube wells in Bangladesh.

The present study examines the mechanisms and possibilities for enhancing As removal from groundwater with naturally occurring $\mathrm{Fe}$ and proposes a reliable, low-cost and sustainable method based on concurrent oxidation of $\mathrm{As}(\mathrm{III})$ and $\mathrm{Fe}^{2+}$ with subsequent association of $\mathrm{As}(\mathrm{V})$ to coagulating/precipitating of $\mathrm{Fe}(\mathrm{OH})_{3}$ flocs. $\mathrm{KMnO}_{4}$ is chosen as the oxidant since it is easy to administer the necessary amount of oxidant based on the color development.

\section{MATERIALS AND METHODS}

\subsection{Chemicals}

All chemicals, $\mathrm{NaHCO}_{3}, \mathrm{NaAsO}_{2}, \mathrm{Na}_{2} \mathrm{HAsO}_{4} \cdot 7 \mathrm{H}_{2} \mathrm{O}, \mathrm{NaOH}, \mathrm{HCl}, \mathrm{NaBH}_{4}, \mathrm{FeCl}_{3} \cdot 6 \mathrm{H}_{2} \mathrm{O}$, $\mathrm{FeCl}_{2} \cdot 4 \mathrm{H}_{2} \mathrm{O}, \mathrm{KMnO}_{4}$ and $\mathrm{Al}_{2}\left(\mathrm{SO}_{4}\right)_{3} \cdot 18 \mathrm{H}_{2} \mathrm{O}$ used in this study are of reagent grade and no additional purification was necessary. For this study a method based on HGAAS (MHS-20) in batch system was developed for As analysis in water using $\mathrm{HCl}$ and $\mathrm{NaBH}_{4}$. The applicability of alum as coagulant was investigated by means of $\mathrm{Al}_{2}\left(\mathrm{SO}_{4}\right)_{3} \cdot 18 \mathrm{H}_{2} \mathrm{O}$. The oxidizing agent was $\mathrm{KMnO}_{4}$. To simulate the concentration of contaminants in groundwater of the Bengal Delta, stock solutions of arsenic and iron were prepared using $\mathrm{NaAsO}_{2}$, 
$\mathrm{Na}_{2} \mathrm{HAsO}_{4} \cdot 7 \mathrm{H}_{2} \mathrm{O}, \mathrm{FeCl}_{3} \cdot 6 \mathrm{H}_{2} \mathrm{O}$, and $\mathrm{FeCl}_{2} \cdot 4 \mathrm{H}_{2} \mathrm{O}$. To adjust the $\mathrm{pH}, \mathrm{NaOH}$ and $\mathrm{HCl}$ were used, while $\mathrm{NaHCO}_{3}$, was used as a buffer.

\subsection{Experiments on oxidation of $\mathrm{As}$ (III) with $\mathrm{KMnO}_{4}$}

The first stage experiments were conducted to study oxidation and removal of As(III) with $\mathrm{KMnO}_{4}$ in the presence of $\mathrm{Fe}^{2+}$ and $\mathrm{Fe}^{3+}$. These experiments were conducted in distilled water with $5 \mathrm{mM} \mathrm{NaHCO}$ as a buffer, with initial $\mathrm{As}(\mathrm{III})$ and $\mathrm{Fe}$ concentrations of 1 and 10 $\mathrm{mg} \mathrm{L}^{-1}$, respectively. $\mathrm{pH}$ was adjusted to 7 by adding dilute $\mathrm{NaOH}$ or $\mathrm{HCl}$ before the addition of $\mathrm{Fe}$ and/or $\mathrm{KMnO}_{4}$. The final $\mathrm{pH}$ varied \pm 0.2 units compared to the set $\mathrm{pH}$ and no attempts were made to adjust the $\mathrm{pH}$ after the addition of $\mathrm{Fe}$. In experiments with $\mathrm{Fe}^{2+}, \mathrm{KMnO}_{4}$ was added at stoichiometric ratio (SR) of $0,0.2,0.7,1$ and 1.3. In experiments with $\mathrm{Fe}^{3+}, \mathrm{KMnO}_{4}$ was added at stoichiometric ratios (SR) of 1. The stoichiometric ratio SR denotes the ratio between added equivalents of oxidant $\left(\mathrm{MnO}_{4}^{-}\right)$and reductants (As(III) and $\mathrm{Fe}^{2+}$ ) in the experimental solutions.

Equations 1 and 2 show oxidation of $\mathrm{As}(\mathrm{III})$ and $\mathrm{Fe}^{2+}$ with $\mathrm{MnO}_{4}^{-}$:

$$
\begin{aligned}
& 3 \mathrm{H}_{3} \mathrm{AsO}_{3}+2 \mathrm{MnO}_{4}^{-} \rightarrow 3 \mathrm{H}_{2} \mathrm{AsO}_{4}^{-}+2 \mathrm{MnO}_{2}+\mathrm{H}_{2} \mathrm{O}+\mathrm{H}^{+} \\
& 3 \mathrm{Fe}^{2+}+\mathrm{MnO}_{4}^{-}+7 \mathrm{H}_{2} \mathrm{O} \rightarrow 3 \mathrm{Fe}(\mathrm{OH})_{3}+\mathrm{MnO}_{2}+5 \mathrm{H}^{+}
\end{aligned}
$$

The $\mathrm{pH}$ generally dropped within the first 10 minutes upon the oxidation and precipitation of $\mathrm{Fe}(\mathrm{OH})_{3}$, followed by an increase due to $\mathrm{CO}_{2}$ expulsion. As(III) concentration was measured continuously after passing an on-line anion exchanger removing $\mathrm{As}(\mathrm{V})$ (Sharma, 2006). Filtered discrete samples $(0.45 \mu \mathrm{m})$ were taken at intervals for measuring total dissolved As concentrations (As(III) + As (V)) and As(III).

\subsection{Experiments on removal of $\mathrm{As}(\mathrm{III})$ with $\mathrm{KMnO}_{4}$ and $\mathrm{Al}_{2}\left(\mathrm{SO}_{4}\right)_{3}$}

Based on the results from the first stage, a second stage of experiments was conducted to improve oxidation and removal of $\mathrm{As}(\mathrm{III})$ with a basic solution of $\mathrm{KMnO}_{4}+\mathrm{Al}_{2}\left(\mathrm{SO}_{4}\right)_{3}$. The effects of the initial Fe concentration, $\mathrm{pH}$, and filtration on removal of As(III) were studied. These experiments were done in a 1:1 mixture of distilled water and tap water to simulate the groundwater conditions in the Bengal Delta. Table 1 shows the composition of the diluted tap water and the average concentrations and range of major ions present in the Bengal plains ground (BGS, 2003). An initial As(III) concentration of $0.5 \mathrm{mg} \mathrm{L}^{-1}$ was chosen for the second stage of experiments in order to simulate the common contamination of arsenic found in groundwaters of the Bengal Delta.

\begin{tabular}{|c|c|c|c|}
\hline \multirow{2}{*}{ Ion } & \multirow{2}{*}{$\begin{array}{c}\text { Tap water (1:1diluted) } \\
(\mathrm{mM})\end{array}$} & \multicolumn{2}{|c|}{ Bangladesh water (mM) } \\
\hline & & Average & Concentration range \\
\hline $\mathrm{Ca}^{2+}$ & 3 & 1.3 & $<0.002-9.1$ \\
\hline $\mathrm{Mg}^{2+}$ & 0.55 & 0.86 & $<0.001-12.5$ \\
\hline $\mathrm{Na}^{+}$ & 1 & 3.9 & $<0.03-118$ \\
\hline $\mathrm{K}^{+}$ & 0.1 & 0.12 & $<0.007-3.4$ \\
\hline $\mathrm{HCO}_{3}^{-}$ & 5.3 & 5.4 & $1.1-11.5$ \\
\hline $\mathrm{Cl}^{-}$ & 0.17 & 1.86 & $0.08-67$ \\
\hline $\mathrm{SO}_{4}^{2-}$ & 0.06 & 0.52 & $<0.002-7.8$ \\
\hline $\mathrm{P}$ & $<0.003$ & 0.025 & $0.003-0.61$ \\
\hline $\mathrm{Si}$ & 0.25 & 0.73 & $0.3-45$ \\
\hline
\end{tabular}

Table 1. Composition of tap water and Bangladesh water (mM). 
The effect of co-occurring iron on As removal was studied in the $\mathrm{Fe}^{2+}$ concentration range of 0 to $10 \mathrm{mg} \mathrm{L}^{-1}$ using a $2 \mathrm{mg} \mathrm{L}^{-1}$ concentration-increasing step. The effect of $\mathrm{pH}$ was studied in the $\mathrm{pH}$ range of $6.0-7.5$, where $\mathrm{pH}$ between 6.0 and 7.5 was adjusted by adding dilute $\mathrm{NaOH}$ or $\mathrm{HCl}$ before the addition of $\mathrm{Fe}$ and/or oxidant. The effect of time of sedimentation on As removal was studied at 0,10 and 20 minutes of sedimentation time. The effect of filtration on As removal compared to prolonged sedimentation time was studied, by filtering the samples 2 minutes after the addition of $\mathrm{Fe}^{2+}$ and oxidant compared to $1 \mathrm{~h}$ and $1.5 \mathrm{~h}$ sedimentation time.

All the experiments were conducted at room temperature $\left(\sim 25^{\circ} \mathrm{C}\right)$. To simulate the anaerobic conditions in groundwater under the plains, nitrogen gas was bubbled through the water for about 10 minutes to reach an oxygen concentration below $2 \mathrm{mg} \mathrm{L}^{-1}$.

\subsection{Lab-scale equipment}

A jar test apparatus (Nordic Scientific - six stirrers) was used at low speed to conduct the experiments in beakers of $1 \mathrm{~L}$ (flash mixing for 1-2 minutes at $90-130 \mathrm{rpm}$ ). The test conditions evaluated different stoichiometric ratios of reagents (range of 0 to 1.3), initial oxidation state of $\mathrm{Fe}$, time of oxidant addition (after 15 and 30 minutes), simultaneous or delayed addition of the oxidant and coagulant reagents; finally, the development of pale pink color was considered.

\subsection{Analytical methods}

As(III) and total As analysis was carried out on a Perkin-Elmer 5000 AAS (Atomic Absorption Spectrometry) using the continuous hydride generation method (Sharma, 2006). To evaluate the oxidation state of arsenic, ion exchange resins were used (mixed-bed ion exchanger composed of $\mathrm{OH}$-form and $\mathrm{H}$-form in ratio 2:1) (SERDOLIT ${ }^{\circledR} \mathrm{MB}$ ). The ion exchange resins were prepared with $1 \mathrm{~g}$ of ion exchanger and cotton wool, put together in a plastic pipette. Total Fe was measured using Flame-AAS (APHA et al., 1995).

\section{RESULTS AND DISCUSSION}

\subsection{As(III) oxidation with $\mathrm{KMnO}_{4}$}

Results for experiments on the effectiveness of $\mathrm{KMnO}_{4}$ on $\mathrm{As}(\mathrm{III})$ oxidation and the effect of presence of $\mathrm{Fe}^{2+}$ on $\mathrm{As}(\mathrm{III})$ oxidation are shown in Figure 1.

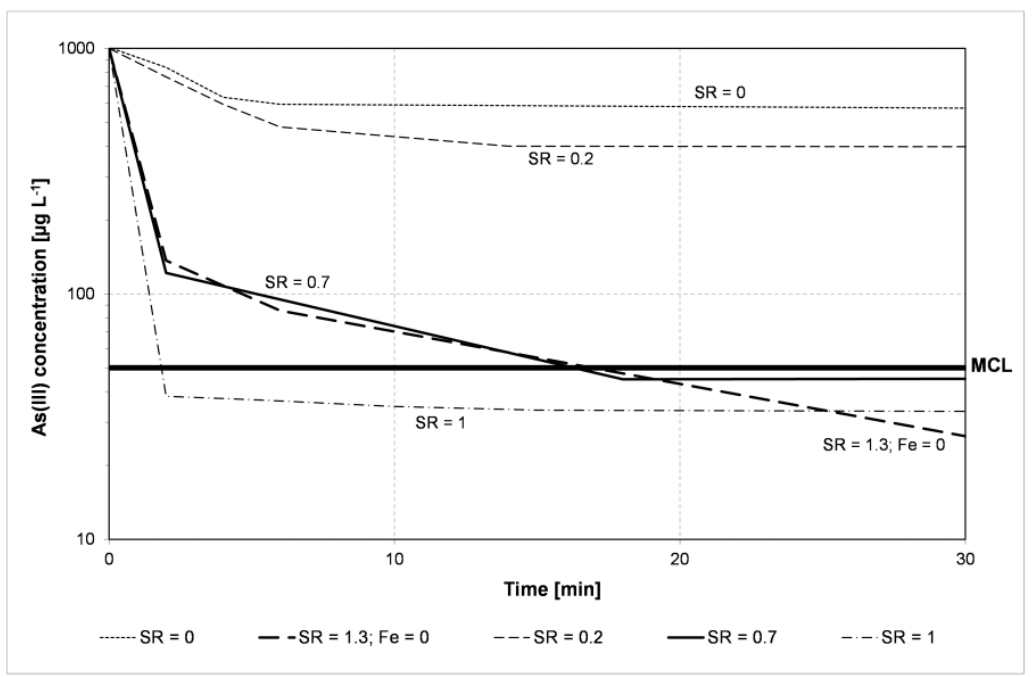

Figure 1. Effect of $\mathrm{KMnO}_{4}$ on oxidation of $\mathrm{As}(\mathrm{III})$ in the presence and absence of $\mathrm{Fe}^{2+}$. Initial $\mathrm{Fe}^{2+}$ concentration: $10 \mathrm{mg} \mathrm{L}^{-1}$. 
As shown in the literature (Hug and Leupin, 2003; Roberts et al., 2004), As(III) oxidation was concomitant with the oxidation of $\mathrm{Fe}^{2+}$ and was very rapid within the first 10 minutes of the experiment, while after this As(III) oxidation was very slow. Furthermore, the results show that a SR of $0.7\left(\mathrm{KMnO}_{4} /\left(\mathrm{As}(\mathrm{III})+\mathrm{Fe}^{2+}\right)\right)$ in presence $\mathrm{Fe}^{2+}$ results in similar oxidation kinetics as a SR of 1.3 in absence of $\mathrm{Fe}^{2+}$. With a $\mathrm{SR}=1$, complete oxidation of As(III) occurs within 2 minutes after the $\mathrm{KMnO}_{4}$ addition in the presence of $\mathrm{Fe}^{2+}$. Ghurye and Clifford (2004) showed that an oxidation yield higher than 95\% was obtained in 15 seconds at similar conditions, but at a $\mathrm{SR}=3$ in the absence of any interfering ions. They also demonstrated that an increase in $\mathrm{pH}$ from 7.3 to 8.3 did not have any effect on the oxidation yield, whereas a decrease in $\mathrm{pH}$ from 7.3 to 6.3 increased the time required for reaching the same oxidation effect.

\subsection{Effect of time of addition of $\mathrm{KMnO}_{4}$ on $\mathrm{As}(\mathrm{III})$ oxidation}

Since $\mathrm{Fe}^{2+}$ is easily oxidized in presence of $\mathrm{O}_{2}$, and pumping and transporting of groundwater in rural areas may take 10-15 minutes, some experiments were done in order to study the influence of a delayed addition of $\mathrm{KMnO}_{4}$ on the oxidation of As(III). The influence of the initial oxidation state of added $\mathrm{Fe}\left(\mathrm{Fe}^{2+}\right.$ or $\mathrm{Fe}^{3+}$ (as sulphate)) on $\mathrm{As}(\mathrm{III})$ oxidation and removal of As was also investigated. Figure 2 shows the results for the oxidation of As(III). $\mathrm{KMnO}_{4}$ was added 15 and 40 minutes after the addition of $\mathrm{Fe}$ and the amount of $\mathrm{KMnO}_{4}$ added was constant at an SR ratio of 1 for oxidation of initial As(III) alone.

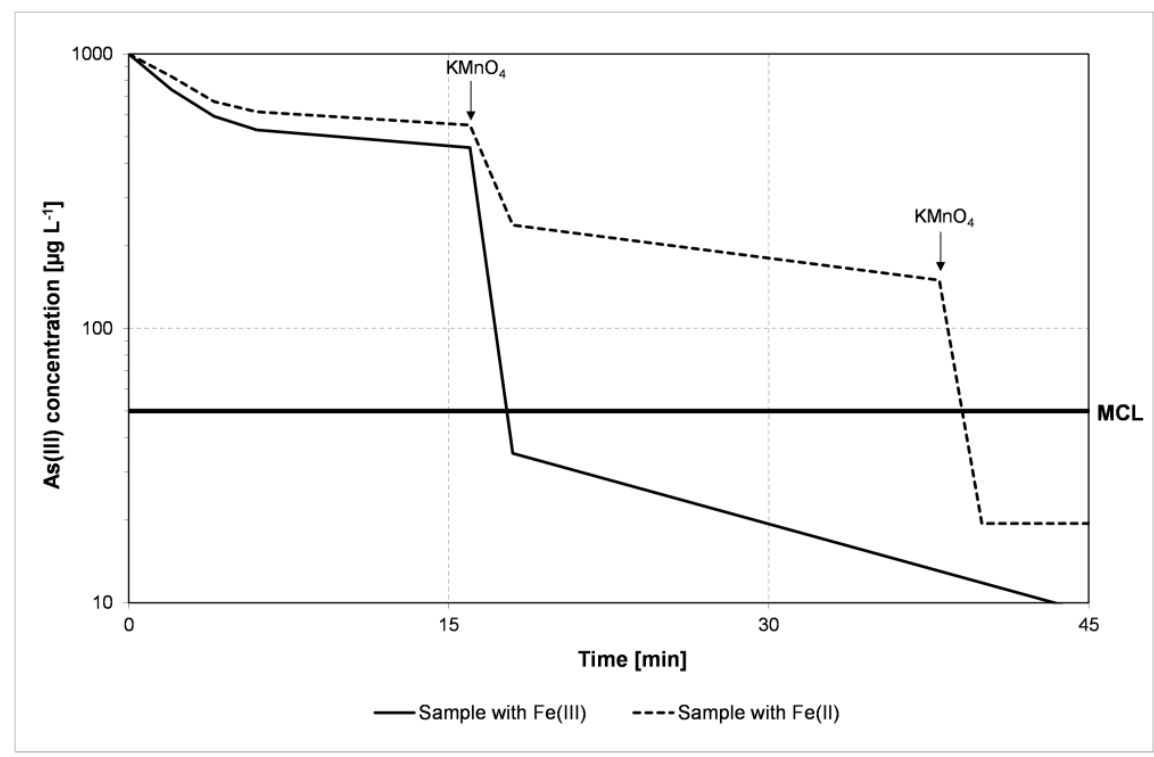

Figure 2. Effect of initial oxidation state of $\mathrm{Fe}$ and time of $\mathrm{KMnO}_{4}$ addition on $\mathrm{As}(\mathrm{III})$ oxidation. In the case of $\mathrm{Fe}^{3+}, \mathrm{KMnO}_{4}$ addition after 15 minutes and in the case of $\mathrm{Fe}^{2+}, \mathrm{KMnO}_{4}$ addition after 15 minutes and 30 minutes. (MCL: Maximum Concentration Level).

The results show that a better oxidation of $\mathrm{As}(\mathrm{III})$ occurred in the presence of $\mathrm{Fe}^{3+}$ in comparison to $\mathrm{Fe}^{2+}$ and in the case of $\mathrm{Fe}^{2+}$ an extra dosage of $\mathrm{KMnO}_{4}$ was required to achieve a final $\mathrm{As}$ (III) concentration below $50 \mu \mathrm{g} \mathrm{L}^{-1}$. This was obviously due to the fact that $\mathrm{Fe}^{2+}$ competes with $\mathrm{As}(\mathrm{III})$ in $\mathrm{KMnO}_{4}$ consumption during the oxidation process. The extra amount of $\mathrm{KMnO}_{4}$ required for oxidation of $\mathrm{As}(\mathrm{III})$ in presence of $\mathrm{Fe}^{2+}$ could be due to incomplete oxidation of $\mathrm{Fe}^{2+}$ before the addition of $\mathrm{KMnO}_{4}$. Comparing Figures 1 and 2 further shows that the presence of $\mathrm{Fe}^{3+}$ had a positive effect on As(III) oxidation, since complete oxidation of As(III) occurred within 2 minutes upon the delayed addition of $\mathrm{KMnO}_{4}$ with initial $\mathrm{Fe}^{3+}$, compared to 20 minutes in the absence of any $\mathrm{Fe}$. 


\subsection{Removal of $\mathrm{As}(\mathrm{III})$ in the presence of $\mathrm{KMnO}_{4}$}

Figure 3 shows removal results of As in filtered samples $(0.45 \mu \mathrm{m})$ for the same experiments as in Figure 2. Figure 3 further shows the removal of As upon immediate addition of $\mathrm{Fe}^{2+}$ and $\mathrm{KMnO}_{4}$ at an $\mathrm{SR}=1$. In the case of delayed $\mathrm{KMnO}_{4}$ addition and $\mathrm{Fe}$ initially present as $\mathrm{Fe}^{3+}, \mathrm{KMnO}_{4}$ was added 15 minutes after the addition of $\mathrm{Fe}$; and in case of delayed $\mathrm{KMnO}_{4}$ addition and $\mathrm{Fe}$ initially present as $\mathrm{Fe}^{2+}, \mathrm{KMnO}_{4}$ was added both 15 minutes and 30 minutes after the addition of $\mathrm{Fe} . \mathrm{KMnO}_{4}$ and $\mathrm{Fe}$ were added concurrently in simultaneous cases. $\mathrm{SR}=0.2$ is equal to the amount of $\mathrm{KMnO}_{4}$ needed for oxidation of As(III) alone. Comparison of Figures 1, 2 and 3 shows that the simultaneous addition of $\mathrm{KMnO}_{4}$ and $\mathrm{Fe}^{2+}$ equal to $\mathrm{SR}=1$ results in both oxidation and removal of As(III) below the MCL within the first couple of minutes of $\mathrm{KMnO}_{4}$ addition. The results also show that the delayed addition of $\mathrm{KMnO}_{4}$ in the presence of $\mathrm{Fe}^{3+}$ did result in sufficient oxidation of As(III) but failed to achieve As removals below the MCL. The lower As removal upon the delayed addition of $\mathrm{KMnO}_{4}$ can be explained by the observation that formation and coagulation of $\mathrm{Fe}(\mathrm{OH})_{3}$ upon addition of $\mathrm{Fe}^{3+}$ is a rapid process and takes less than 5 seconds in the case of $\mathrm{Fe}^{3+}$ (Crosby et al., 1983). Because As(V) is better adsorbed compared to $\mathrm{As}(\mathrm{III})$ on $\mathrm{Fe}(\mathrm{OH})_{3}$, the best removal of As would be achieved when $\mathrm{As}(\mathrm{V})$ is present during formation of $\mathrm{Fe}(\mathrm{OH})_{3}$. The results further show that the delayed addition of $\mathrm{KMnO}_{4}$ resulted in higher As(III) removals compared to the simultaneous addition of $\mathrm{KMnO}_{4}$ at $\mathrm{SR}=0.2$ (which is equal to SR 1 of As(III) alone) and initial $\mathrm{Fe}^{2+}$.

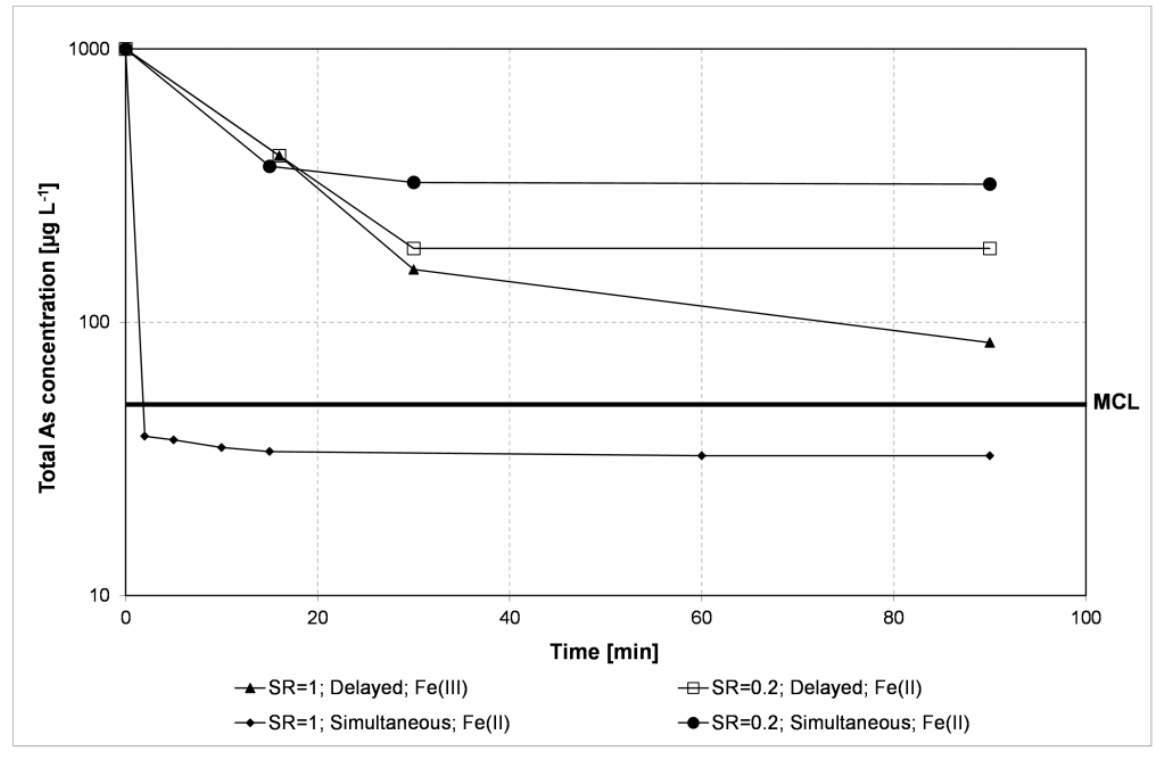

Figure 3. Effects of initial oxidation state of $\mathrm{Fe}$ and time of $\mathrm{KMnO}_{4}$ addition on total As removal in filtered samples $(0.45 \mu \mathrm{m})$.

The observed positive effect of the delayed addition of $\mathrm{KMnO}_{4}$ on $\mathrm{As}(\mathrm{III})$ oxidation could be explained in two ways, when $\mathrm{Fe}^{2+}$ is used. The first is that As(III) oxidation occurs in parallel to $\mathrm{Fe}^{2+}$ oxidation and hence lower As(III) concentrations would be present upon the delayed addition of $\mathrm{KMnO}_{4}$. The second is that the interfering effect of $\mathrm{Fe}^{2+}$ reduces with time due to the oxidation of the $\mathrm{Fe}^{2+}$, with oxygen (natural oxidation with air), resulting in lower $\mathrm{Fe} 2+$ concentrations. The different effect of the time of $\mathrm{KMnO}_{4}$ addition on As removals can also be explained based upon the oxidation of $\mathrm{Fe}^{2+}$ with oxygen. Literature reports that the oxidation of $\mathrm{Fe}^{2+}$ with $\mathrm{O}_{2}$ depends on many factors (Wolthoorn et al., 2004; Tufekci and Sarikaya, 1996; Moses and Herman, 1989). Calculations based on Sung and Morgan (1980) show that complete oxidation of $\mathrm{Fe}^{2+}$ was not achieved within 15 minutes after the addition of $\mathrm{Fe}^{2+}$ and approximately $1 / 3$ of the initial $\mathrm{Fe}^{2+}$ was still present as $\mathrm{Fe}^{2+}$. Addition of $\mathrm{KMnO}_{4}$ at 
this time would result in the oxidation of remaining $\mathrm{Fe}^{2+}$ and $\mathrm{As}(\mathrm{III})$. Oxidation of $\mathrm{Fe}^{2+}$ would result in the formation of additional $\mathrm{Fe}(\mathrm{OH})_{3}$, leading to higher As removals. This positive effect of the delayed addition of $\mathrm{KMnO}_{4}$ on As removals would only be observed if $\mathrm{Fe}^{2+}$ is present, resulting in freshly formed $\mathrm{Fe}(\mathrm{OH})_{3}$. If $\mathrm{KMnO}_{4}$ is added after the complete oxidation of $\mathrm{Fe}^{2+}$ and subsequent coagulation of $\mathrm{Fe}(\mathrm{OH})_{3}$, no further As removals would take place, as it was observed when an additional amount of $\mathrm{KMnO}_{4}$ was added 40 minutes after the addition of $\mathrm{Fe}^{2+}$ to achieve the complete oxidation of $\mathrm{As}(\mathrm{III})$. These results indicate that if an insufficient amount of $\mathrm{KMnO}_{4}$ is added simultaneously with $\mathrm{Fe}^{2+}, \mathrm{KMnO}_{4}$ would be utilized to oxidize $\mathrm{Fe}^{2+}$. Upon delayed addition of $\mathrm{KMnO}_{4}$, most of the $\mathrm{Fe}^{2+}$ is oxidized in the presence of oxygen and the added $\mathrm{KMnO}_{4}$ would oxidize the remaining $\mathrm{Fe}^{2+}$ and $\mathrm{As}(\mathrm{III})$. The outcome is that oxidation with $\mathrm{KMnO}_{4}$ proves to be a promising method. Enough $\mathrm{KMnO}_{4}$ should be added to oxidize both the $\mathrm{Fe}^{2+}$ and the $\mathrm{As}$ (III) immediately after collecting the water. Incomplete oxidation of As(III) may be one of the reasons for the reported poor performance of some of the removal methods applied in the field based on the coagulation principle. For example, a study by Cheng et al. (2004) reported that the residual As concentrations in the field were in the form of As(III). The As removal was based on $\mathrm{Ca}(\mathrm{ClO})_{2}$ as an oxidizing agent and $\mathrm{Fe}^{3+}$ added in the form of $\mathrm{Fe}_{2}\left(\mathrm{SO}_{4}\right)_{3}$. In the two bucket systems developed by DANIDA (Danish development assistance program) only $2 \mathrm{mg} \mathrm{L}^{-1}$ $\mathrm{KMnO}_{4}(13 \mu \mathrm{M})$ is used for oxidation of As(III) (BAMWSP, 2001). Our results indicate that the added $\mathrm{KMnO}_{4}$ will not be sufficient if $\mathrm{Fe}^{2+}$ is present, as it is in most groundwaters under alluvial plains. Based on these results, it can be concluded that the removal of As with naturally occurring $\mathrm{Fe}$ was greatly improved by adding sufficient amounts of $\mathrm{KMnO}_{4}$ to oxidise both $\mathrm{As}(\mathrm{III})$ and $\mathrm{Fe}^{2+}$.

\subsection{A practical method for oxidation and removal of $\mathrm{As}(\mathrm{III})$ using $\mathrm{KMnO}_{4}+\mathrm{Al}_{2}\left(\mathrm{SO}_{4}\right)_{3}$}

In devising a practical method for field application, three major obstacles are evident:

- fast oxidation is necessary in order to form $\mathrm{As}(\mathrm{V})$ before all $\mathrm{Fe}^{2+}$ is precipitated;

- naturally occurring $\mathrm{Fe}$ is not always present in adequate concentrations (example $\mathrm{Fe} / \mathrm{As}>120$ in Bangladesh with co-occurrence of competing ions) in all groundwaters;

- filtering/sedimentation of flocs with adsorbed As is probably necessary;

- interfering ions (P and Si) can considerably decrease As removal efficiency.

The three first points can be solved most conveniently by adding an oxidant $\left(\mathrm{KMnO}_{4}\right)$ together with an auxiliary coagulant $(\mathrm{Al})$ if $\mathrm{Fe}^{2+}$ is present at low concentrations. Therefore, efforts were made to prepare a solution, which carried both oxidizing capacity and coagulation ability. The fourth point is illustrated in earlier studies on the effect of ions on As removal (Sharma, 2006), which showed that the presence of high P and Si concentrations increased the colloidal stability and hence decreased the As removal efficiency. Therefore, this study focused on the addition of coagulants like $\mathrm{Al}$ and $\mathrm{Fe}$ for destabilising the colloids and increasing the floc size for enhanced filterability. A single aqueous solution of $\mathrm{KMnO}_{4}$ and the coagulant $\mathrm{Fe}^{2+}$ cannot be made since $\mathrm{Fe}$ would be oxidized. Laboratory observation shows that a solution of $\mathrm{KMnO}_{4}$ and $\mathrm{Al}_{2}\left(\mathrm{SO}_{4}\right)_{3}\left(0.06 \mathrm{M}\right.$ of $\mathrm{Al}_{2}\left(\mathrm{SO}_{4}\right)_{3}$ and $0.02 \mathrm{M}$ of $\left.\mathrm{MnO}_{4}{ }^{-}\right)$is stable for years at $\mathrm{pH} \sim 11$ adjusted with $\mathrm{NaOH}$. At this strength, a volume of 1-3 mL per liter of water is sufficient and it is an optimal volume to handle in practice. The total concentrations and the molar ratios of the reagents can be widely altered to suit the predominant types of groundwater to be treated. Results for the applicability of this solution at varying $\mathrm{Fe}$ concentrations at an initial As concentration of $500 \mu \mathrm{g} \mathrm{L}^{-1}$ are shown in Figure 4. The effect of adding this solution in an amount exactly equal to $S R=1$ and in amounts equal to a slight excess indicated by the appearance of a faint pink color 
(very dilute $\mathrm{MnO}_{4}$ ) is shown. Moreover, the effect of the reaction time required for maximum As removals was studied for both SRs.

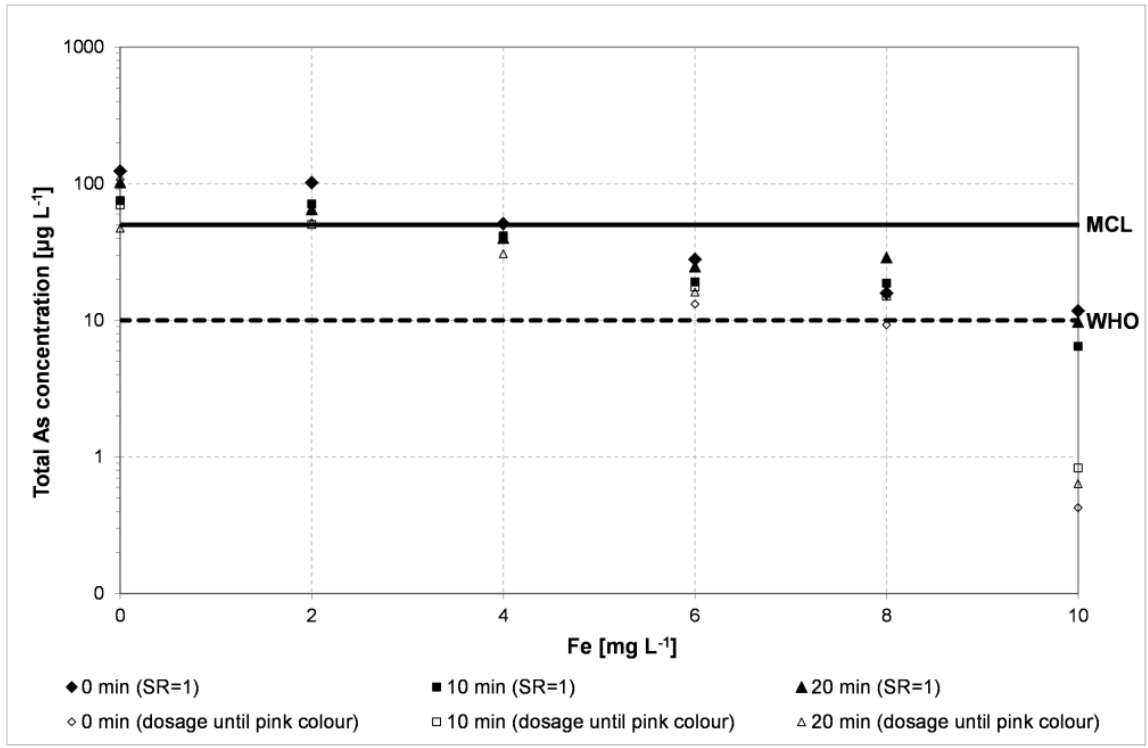

Figure 4. Influence of initial Fe concentration, time of sedimentation and amount of $\mathrm{KMnO}_{4}+\mathrm{Al}$ on As removals at an initial As(III) concentration of $500 \mu \mathrm{g} \mathrm{L}^{-1}$ in filtered samples $(0.45 \mu \mathrm{m})$. Filled symbols represent the addition of $\mathrm{KMnO}_{4}$ and $\mathrm{Al}$ equal to $\mathrm{SR}=1$ and open symbols represent a slight excess of $\mathrm{KMnO}_{4}$ and $\mathrm{Al}$ until a pink color appears. 0, 10 and 20 min represent sedimentation times.

As expected, the results show that higher Fe concentrations increase As removal and As concentrations below the MCL of $50 \mu \mathrm{g} \mathrm{L}^{-1}$ were achieved at an initial $\mathrm{Fe} / \mathrm{As}$ ratio of 11 or above. Moreover, the figure shows that slightly better As removal was achieved when the $\mathrm{KMnO}_{4}+\mathrm{Al}$ solution was added in slight surplus to attain the pink color and a slightly better removal was achieved with a reaction time of 10-20 minutes compared to a 0 time of sedimentation. In all cases, the daily generation of As contaminated sludge is very low; however, care should be taken to avoid the disposal of the sludge near children's playing area or edible crops. A suitable way of disposal of this sludge would be to bury it. Instead of waiting for an expensive solution based upon construction of deep-tube wells, taking years and reaching few, removal of As based on naturally occurring Fe along with application of $\mathrm{KMnO}_{4}$ supplemented with Fe/Al could be recommended as a mitigating option for the affected rural areas of the Bengal Delta. The application of chemicals in solution would result in better mixing and the results showed that this mixture would have great potential for the treatment of As. However, field verification is required.

Moreover, currently there is no evidence that potassium levels in municipally treated drinking water, even water treated with potassium permanganate, are likely to pose any risk to the health of consumers. It is not considered necessary to establish a health-based guideline value for potassium in drinking-water (WHO, 2011).

\subsection{Advantages of adding oxidant and coagulant simultaneously to water}

The advantage of using $\mathrm{KMnO}_{4}$ together with $\mathrm{Al}_{2}\left(\mathrm{SO}_{4}\right)_{3}$ is that addition of $\mathrm{Al}$ ions increases the filterability of the $\mathrm{Fe}(\mathrm{OH})_{3}$ flocs, which grow larger in the presence of $\mathrm{Al}$. An added advantage of using the strongly basic mixture is the neutralization of the acidity produced due to $\mathrm{Fe}(\mathrm{OH})_{3}$ and $\mathrm{Al}(\mathrm{OH})_{3}$ formation. This could in turn lower residual soluble $\mathrm{Al}$ concentrations and hence limit potential adverse health effects. The third advantage is that by 
increasing the amount of added $\mathrm{Al}$ the method can be applied in waters with low $\mathrm{Fe}$ concentrations. The results on the effect of filtration as a useful step for adequate As removal are shown in Figure 5. It clearly demonstrates that filtration after flocculation for 20 minutes removed most As, and As concentrations below $50 \mu \mathrm{g} \mathrm{L}^{-1}$ were achieved at Fe concentrations of $5 \mathrm{mg} \mathrm{L}^{-1}$, i.e., at Fe/As ratio of 13. At higher Fe/As ratios, As concentrations below $10 \mu \mathrm{g}$ $\mathrm{L}^{-1}$ were achieved. Without filtration too much As is tied to dispersed colloids and flocs. The effect of $\mathrm{pH}$ on As removal using the $\mathrm{KMnO}_{4}+\mathrm{Al}_{2}\left(\mathrm{SO}_{4}\right)_{3}$ mixture was also investigated in the $\mathrm{pH}$ range of 6.0-7.5, and the results are shown in Figure 6. The results show that As(III) oxidation and removal was slightly higher at higher $\mathrm{pH}$; however, As removal below $50 \mu \mathrm{g} \mathrm{L}$ ${ }^{1}$ was achieved in the studied $\mathrm{pH}$ range. This is probably due to the buffering capacity of the $\mathrm{KMnO}_{4}+\mathrm{Al}_{2}\left(\mathrm{SO}_{4}\right)_{3}$ solution. A previous study (Sharma, 2006), without addition of any oxidizing agent, showed that As(III) removal was reduced by approximately $40 \%$ at $\mathrm{pH} 6$ compared with $\mathrm{pH} 7$.

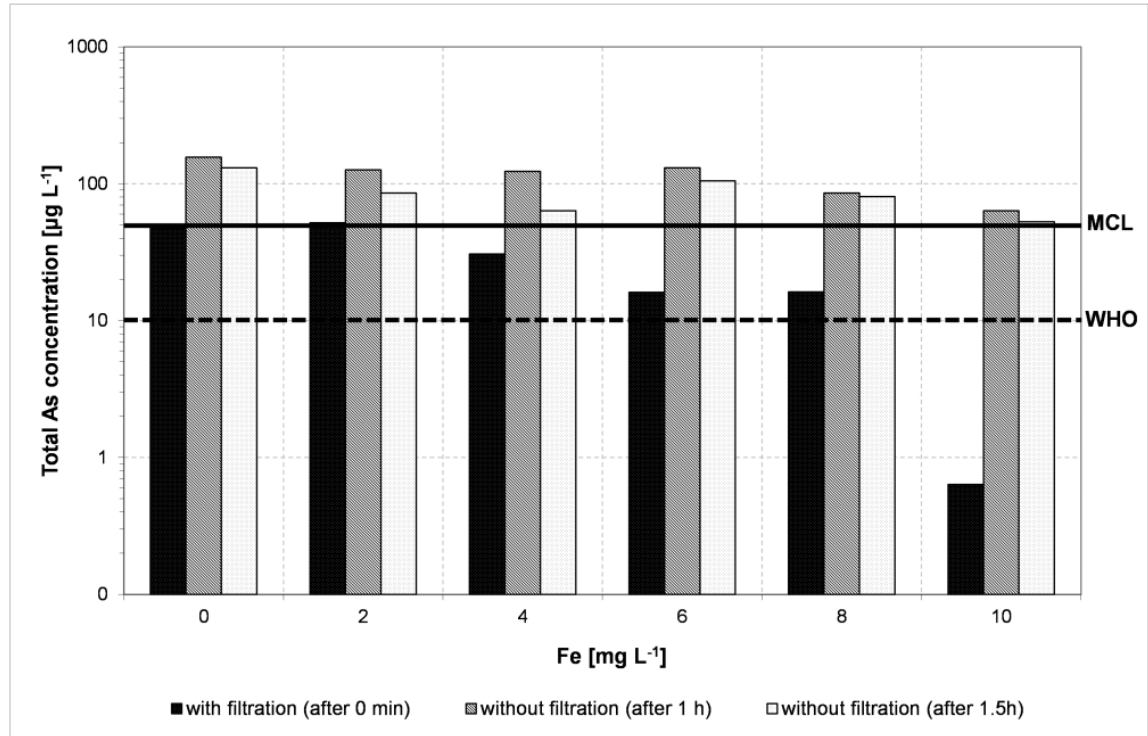

Figure 5. Removal of As in filtered and non-filtered samples with different $\mathrm{Fe}$ concentrations after treatment to pink color of the $\mathrm{KMnO}_{4}+\mathrm{Al}_{2}\left(\mathrm{SO}_{4}\right)_{3}$ solution.

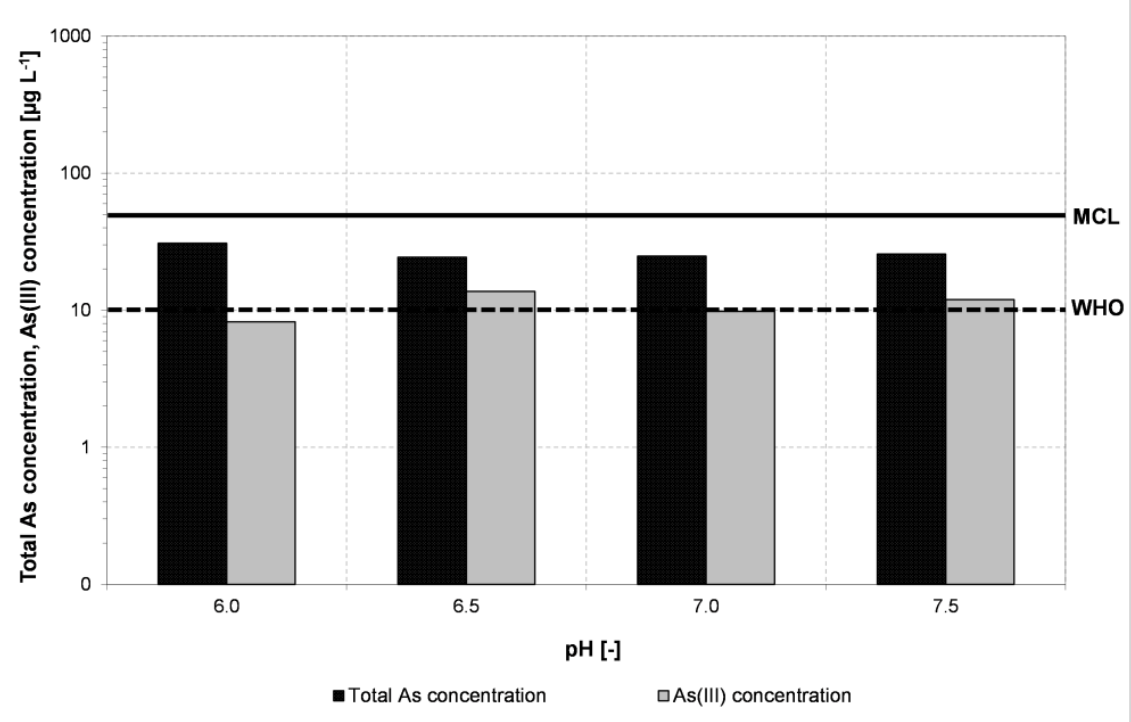

Figure 6. Effect of $\mathrm{pH}$ on oxidation and removal of $\mathrm{As}(\mathrm{III})$ in filtered samples $(0.45 \mu \mathrm{m})$ at $\mathrm{SR}=1$ using $\mathrm{KMnO}_{4}+\mathrm{Al}_{2}\left(\mathrm{SO}_{4}\right)_{3}$ solution. 


\section{CONCLUSIONS}

This work shows that oxidation of As(III) can effectively be obtained by adding $\mathrm{KMnO}_{4}$, until a pale pink color occurs, immediately after collecting the groundwater in order to improve the passive sedimentation with initial $\mathrm{Fe}^{2+}$ precipitating as $\mathrm{Fe}(\mathrm{OH})_{3}$ flocs after oxidation. Moreover, the results show that presence of $\mathrm{Fe}^{2+}$ has a positive effect of As(III) oxidation with $\mathrm{KMnO}_{4}$.

The practical effect of using $\mathrm{KMnO}_{4}$ can be greatly improved if a strongly basic solution of $\mathrm{MnO}_{4}{ }^{-}$and $\mathrm{AlO}_{2}{ }^{-}$is added. The advantages of using this solution are easy oxidation and floc formation, and it can be applied to waters in the $\mathrm{pH}$ range of 6.0-7.5. To achieve sufficient As removals, treated water filtering is necessary.

The treatment of $\mathrm{Fe}^{2+}$ and $\mathrm{As}(\mathrm{III})$ laden groundwater can easily be achieved by the addition of a basic solution of $\mathrm{KMnO}_{4}$ and $\mathrm{AlO}_{2}$ to aid the oxidation and floc and total As concentrations below $50 \mu \mathrm{g} \mathrm{L}^{-1}$ can be achieved at Fe/As ratios of 13. At Fe/As ratios above 13, the total As concentrations can be even below the newest WHO recommendation of $10 \mu \mathrm{g} \mathrm{L}^{-1}$. This is an appropriate solution that can be applied in rural areas with decentralized water supply and high $\mathrm{Fe}$ and As concentrations in water due to the simple operation (coagulant and oxidant agents could be added together and the color change could give a good indication while adding the solution). This solution is highly reliable in operation, uses minimum energy and requires low levels of investment in the plant. The reagents are easily available in developing countries and they are well known by villagers. The addition of $\mathrm{Al}$ could improve the filterability due to the formation of bigger particles. There is no evidence that potassium levels in municipally treated drinking water, even water treated with potassium permanganate, are likely to pose any risk to the health of consumers. The daily generation of As contaminated sludge is very low; however, care should be taken in disposal of the sludge and it should not be disposed near children's playing areas or near edible crops. A suitable way of disposal would be to bury the sludge, dispose of it with other solid wastes, solidify it in concrete or discharge it in sanitary latrines. This solution may be applied also in industrialized countries because it does not involve expensive upgrading in small- to medium-sized water treatment plants that already have either a coagulation or filtration unit.

\section{ACKNOWLEDGMENT}

The research presented in this paper was developed during the Erasmus programme of Barbara Marianna Crotti and Monica Anselmi at DTU Copenhagen. The authors would like to thank Monica Anselmi for her collaboration during the experimental tests.

\section{REFERENCES}

AHMED, F.; RAHMAN, M. Low-Cost water supply technologies. In: AHMED, F.; RAHMAN, M. (Eds.). Water supply \& sanitation: rural and low income urban communities. Dhaka: ITN-Bangladesh, 2003. p. 407-441.

AHMED, F. An overview of arsenic removal technologies in Bangladesh and India. 2013. http://citeseerx.ist.psu.edu/viewdoc/summary?doi=10.1.1.161.3728

AMERICAN PUBLIC HEALTH ASSOCIATION - APHA; AMERICAN WATER WORKS ASSOCIATION - AWWA; WATER ENVIRONMENT FEDERATION - WEF. Direct air-acetylene flame method. In: APHA; AWWA; WEF. Standard methods for the examination of water and waste water. Washington, 1995. p. 3-13-3-15. 
BANGLADESH ARSENIC MITIGATION WATER SUPPLY PROJECT - BAMWSP. Rapid assessment of household level arsenic removal technologies. Phase II Report. Dhaka, 2001.

BERG, M.; STENGEL, C.; TRANG, P. T. K.; VIET, P. H.; SAMPSON, M. L.; LENG, M.; et al. Magnitude of arsenic pollution in the Mekong and Red River Deltas - Cambodia and Vietnam. Science of the Total Environment, v. 372, n. 2-3, p. 413-425, 2007. http://dx.doi.org/10.1016/j.scitotenv.2006.09.010

BORTOLOI, S.; NATH, S. K.; GOGOI, S.; DUTTA, R. K. Arsenic and iron removal from groundwater by oxidation-coagulation at optimized $\mathrm{pH}$ : laboratory and field studies. Journal of Hazardous Materials, v. 260, p. 618-626, 2013. http://dx.doi.org/10.1016/j.jhazmat.2013.06.017

BRITISH GEOLOGICAL SURVEY - BGS. Bangladesh: DPHE/BGS National Hydrochemical Survey. 〈http://www.bgs.ac.uk/arsenic/bangladesh/datadownload.htm>. Access: Sep. 2003.

CHAKRABORTI, D.; SENGUPTA, M. K.; RAHMAN, M. M.; AHAMED, S.; CHOWDHURY, U. K.; HOSSAIN, M. A. et al. Groundwater arsenic contamination and its health effects in the Ganga-Meghna-Brahmaputra plain. Journal of Environmental Monitoring, v. 6, p. 74N-83N, 2004.

CHENG, Z.; VAN GEEN, A.; JING, C.; MENG, X.; SEDDIQUE, A.; AHMED, K. M. Performance of a household-level arsenic removal system during 4-month deployments in Bangladesh. Environmental Science and Technology, v. 38, n. 12, p. 3442-3448, 2004. http://dx.doi.org/10.1021/es0352855

CHERRY, J. A.; SHAIKH, A. U.; TALLMAN, D. E.; NICHOLSON, R. V. Arsenic species as an indicator of redox conditions in groundwater. Journal of Hydrology, v. 43, n. 14, p. 373-392, 1979. http://dx.doi.org/10.1016/0022-1694(79)90182-3

CROSBY, S. A.; GLASSON, D. R.; CUTTLER, A. H.; BUTLER, I.; TURNER, D. R.; WHITFIELD, M. et al. Surface-Areas and Porosities of Fe(III)-Derived and Fe(II)Derived Oxyhydroxides. Environmental Science and Technology, v. 17, n. 12, p. 709713, 1983. http://dx.doi.org/10.1021/es00118a004

GHURYE, G.; CLIFFORD, D. As(III) oxidation using chemical and solid-phase oxidants. Journal of American Water Works Association, v. 96, n. 1, p. 84-96, 2004. http://www.jstor.org/stable/41311973

HUG, S. J.; LEUPIN, O. Iron-catalyzed oxidation of arsenic(III) by oxygen and by hydrogen peroxide: $\mathrm{pH}$-dependent formation of oxidants in the Fenton reaction. Environmental Science and Technology, v. 37, n. 12, p. 2734-2742, 2003. http://dx.doi. org/10.1021/es026208x

HUG, S. J.; LEUPIN, O. X.; BERG, M. Bangladesh and Vietnam: Different groundwater compositions require different approaches to arsenic mitigation. Environmental Science and Technology, v. 42, n. 17, p. 6318-6323, 2008. http://dx.doi.org/10.1021/es7028284

MAMTAZ, R.; BACHE, D. H. Reduction of arsenic in groundwater by coprecipitation with iron. Journal of Water Supply - Aqua, v. 50, n. 5, p. 313-324, 2001. 
MENG, X.; KORFIATIS, G.; CHRISTODOULATOS, C.; BANG, S. Treatment of arsenic in Bangladesh well water using a household co-precipitation and filtration system. Water Research, v. 35, n. 12, p. 2805-2810, 2001. http://dx.doi.org/10.1016/S00431354(01)00007-0

MOSES, C. O.; HERMAN, J. S. Homogeneous oxidation-kinetics of aqueous ferrous iron at circumneutral ph. Journal of Solution Chemistry, v. 18, n. 8, p. 705-725, 1989. http://dx.doi.org/10.1007/BF00651804

ROBERTS, L. C.; HUG, S. J.; RUETTIMANN, T.; BILLAH, M.; KHAN, A. W.; RAHMAN, M. T. Arsenic removal with Iron(II) and Iron(III) in waters with high silicate and phosphate concentrations. Environmental Science and Technology, v. 38, n. 1, p. 307-315, 2004. http://dx.doi.org/10.1021/es0343205

SHARMA, A. K. Arsenic removal from water using naturally occurring Iron, and the associated benefits on health in affected regions. Kgs. Lyngby: Institute of Environment \& Resources, Technical University of Denmark, 2006.

SHARMA, A. K.; TJELL, J. C.; MOSBÆK, H. Natural arsenic in groundwater. Occurrence, remediation and management. In: PRE-CONGRESS WORKSHOP NATURAL ARSENIC IN GROUNDWATER (BWO6); INTERNATIONAL GEOLOGICAL CONGRESS, 32., August 18-19 2004, Florence, Italy. Proceedings... Leiden: A.A. Balkema, 2005. p. 263-271.

SMEDLEY, P. L.; KINNIBURGH, D. G. A review of the source, behaviour and distribution of arsenic in natural waters. Applied Geochemistry, v. 17, n. 5, p. 517-568, 2002. http://dx.doi.org/10.1016/S0883-2927(02)00018-5

SORLINI, S.; GIALDINI, F. Conventional oxidation treatments for the removal of arsenic with chlorine dioxide, hypochlorite, potassium permanganate and monochloramine. Water Research, v. 44, p. 5653-5659, 2010. http://dx.doi.org/10.1016/j.watres. 2010.06.032

SUNG, W.; MORGAN, J. J. Kinetics and Products of ferrous iron oxygenation in aqueous systems. Environmental Science and Technology, v. 14, n. 5, p. 561-568, 1980. http://dx.doi.org/10.1021/es60165a006

TUFEKCI, N.; SARIKAYA, H. Z. Catalytic effects of high Fe(III) concentrations on Fe(II) oxidation. Water Science and Technology, v. 34, n. 7-8, p. 389-396, 1996. http://dx.doi.org/10.1016/S0273-1223(96)00770-6

WORLD HEALTH ORGANIZATION - WHO Guidelines for drinking water quality. Geneva, 2011. Available in: http://www.who.int/water_sanitation_health/waterquality/guidelines/dwq-guidelines-4/en/. Access in: Sep. 2013.

WOLTHOORN, A.; TEMMINGHOFF, E. J. M.; WENG, L.; VAN RIEMSDIJK, W. H. Colloid formation in groundwater: effect of phosphate, manganese, silicate and dissolved organic matter on the dynamic heterogeneous oxidation of ferrous iron. Applied Geochemistry, v. 19, n. 4, p. 611-622, 2004. http://dx.doi.org/10.1016/j.apgeochem.2003.08.003 